\title{
Economic impacts of individual climate change mitigation options in the U.S. forest sector
}

\author{
Steven M. Winnett ${ }^{1}$, Richard W. Haynes ${ }^{2}$, William G. Hohenstein ${ }^{1}$ \\ 'U.S. Environmental Protection Agency, Climate Change Division, Office of Policy, Planning and Evaluation, \\ Washington, DC 20460, USA \\ ${ }^{2}$ USDA Forest Service, Pacific Northwest Forest Experiment Station, Portland, Oregon 97208, USA
}

\begin{abstract}
Economic and carbon (C) impacts of 3 greenhouse gas mitigation options in the U.S. forest sector are presented and compared to a baseline. Options analyzed include 2 levels of large-scale tree planting on marginal crop and pasture land, and increasing the use of recycled paper in the paper making process. The scenarios differ in the timing and magnitude of their economic impacts, and in their effects on C storage. All 3 options increase forest area and/or inventories, and have significant benefits toward increasing the sequestration of $\mathrm{C}$. The economic condition of forest product consumers and producers are little affected by the options. However, decreases in timber prices caused by the increases in wood supplies have severe negative impacts on forest landowners. Actions which could moderate the adverse economic impacts of these $\mathrm{C}$ conservation and sequestration scenarios are discussed.
\end{abstract}

\section{INTRODUCTION}

In 1988 , the United States emitted roughly $1.3 \mathrm{Pg}$ (petagrams, $\times 10^{15} \mathrm{~g}$ ) of carbon (C) in the form of the greenhouse gas (GHG) carbon dioxide (U.S. DOS 1992). Annual $\mathrm{C}$ emissions are projected to increase at a rate of approximately 0.013 to $0.014 \mathrm{Pg}$ annually through the year 2000 (U.S. DOS 1992). ${ }^{1}$ The ability of terrestrial plants to assimilate carbon dioxide $\left(\mathrm{CO}_{2}\right)$ and store $C$ offers unique opportunities to mitigate increasing U.S. GHG emissions. Forest sector activities have been implemented or have been under consideration which can reduce the rate of GHG emissions and increase storage of C (Wisniewski et al. 1993, this volume, p. 1-5). There are, however, secondary economic impacts resulting from these activities which have the potential to cause economic hardship to consumers or producers of forest products if not moderated through adjustments in policies. Policy makers need to understand potential negative impacts and adjust their GHG mitigation programs accordingly.

\footnotetext{
'The following units are used in this paper. One petagram (Pg) equals one billion $\left(10^{9}\right)$ metric tons. One teragram $(\mathrm{Tg})$ equals one million $\left(10^{6}\right)$ metric tons. One megagram (Mg) equals one metric ton
}

Over the past several years, changes in global and domestic forest management practices and policies have been evaluated which have the potential to reduce the rate of GHG emissions (Moulton \& Richards 1990, Peer et al. 1991, Dixon et al. 1993a, b). Past analyses have largely concentrated on 1 or 2 factors. Some have evaluated the likely impacts of proposed forest management activities on $\mathrm{C}$ sequestration or conservation. Others have examined the costs of executing a program of a certain type, or have calculated the economic impacts resulting from a promising forest management activity (Winjum \& Lewis 1993, this volume, p. 111-119). None of the previous analyses have evaluated the full range of economic implications and quantified the likely physical effects.

This paper reports preliminary results of a study which examines both the primary costs and secondary economic impacts, as well as physical C effects, of U.S. policy options designed to stabilize the buildup of GHGs in the atmosphere. We present the initial results of the forest sector analysis, and concentrate primarily on the economic impacts of the options investigated. The $\mathrm{C}$ fluxes resulting from the options analyzed are reported to indicate the relative benefit of each activity in terms of GHG sequestration. 


\section{METHODOLOGY}

The forest sector $\mathrm{C}$ conservation and sequestration options analyzed include increasing the use of recycled paper, and large-scale planting of trees on marginal crop and pasture land. Scenarios were run to determine the economic and land use impacts of the options using the Timber Assessment Market Model (TAMM) and Aggregated Timberland Assessment System (ATLAS). ${ }^{1}$ We then used the land-use results in 2 forest $\mathrm{C}$ models, FORCARB and $\mathrm{FCM}_{1}{ }^{2}$ to evaluate impacts on $\mathrm{C}$ conservation and sequestration.

The economic impacts of these options on producers and consumers are evaluated by examining changes in both welfare and the market. In the forest sector, we focus on wood product consumers and producers, and on the landowners who grow the trees, or stumpage. We use the concept of consumer and producer surplus as an indicator of their condition, then examine changes in forest inventories and harvest, revenues, and prices to illustrate the reasons for any change. The results of the $C$ analysis give an indication of the scale of the GHG benefits that may be possible. This approach does not estimate the benefits of reducing GHGs, or attempt to make assumptions about the changes in other net social benefits associated with these options.

The TAMM model simulates economic trends for the entire U.S. forest sector. It has been used since the late 1970 s by the Forest Service for its periodic Resource Planning Act (RPA) Assessment forecasts (Adams \& Haynes 1980, Haynes \& Adams 1985), and in various policy studies (Adams \& Haynes 1990, 1991a, b). It provides long-term projections of price, consumption and production trends in the forest sector, and can simulate the effect of forest policies and programs over a $50 \mathrm{yr}$ period. It is an econometrically based model which solves iteratively for an equilibrium solution. Demand for forest products is driven by exogenously derived indicators of macroeconomic activity, such as housing starts, population and GNP (gross national product) growth. Supply is a function of stumpage price (price of trees as yet uncut) and timber inventory. A forest inventory projection system, ATLAS, tracks inventory

\footnotetext{
${ }^{1}$ Scenarios were generated and simulations conducted by R. W. Haynes, R. J Alig and E. Moore of the USDA Forest Service Pacific Northwest Forest Experiment Station, Portland, OR

${ }^{2}$ The results from the FORCARB model were generated by R. A. Birdsey and L. H. Heath, USDA Forest Service Northeast Forest Experiment Station, Radnor, PA. Results from the FCM model were generated by D. P. Turner, G. J Koerper and J. R. Barker, ManTech Environ. Tech., and J. Lee, U.S. Environmental Protection Agency Environmental Research Laboratory, Corvallis, OR
}

changes based on timber growth and harvest (Mills \& Kincaid 1992).

The combined TAMM/ATLAS model projects changes in regional and national inventory and harvest levels, stumpage and finished product prices, and product production and consumption for specified scenarios. In addition, the model provides employment levels and welfare data. Inventory and harvest outputs from the ATLAS model are used as inputs for the calculation of $\mathrm{C}$ inventories and fluxes. The TAMM/ATLAS model was first used in conjunction with changes in climatic conditions as a method for valuing acidic deposition and air pollution effects on forests as part of the National Acid Precipitation Assessment Program (Haynes \& Kaiser 1990).

Both of the $C$ models, FORCARB and FCM, combine projections of inventory changes, forest area, and harvest with estimates of $\mathrm{C}$ in forest ecosystem components on the basis of region, owner, forest type and condition, and stand age (Plantinga \& Birdsey 1993, Turner et al. 1993). The models use a set of $C$ budgets which were constructed using growth and yield tables to calculate wood volume, then add the remaining $\mathrm{C}$ in trees, woody debris, understory, forest floor and soil. The results of the 2 models define the bounds of a range for additional $C$ stored in private lands and National Forests in response to the options analyzed. We present the results as additional $C$ sequestered, cumulatively, above baseline levels

Considerable uncertainty exists in the understanding and measurement of $\mathrm{C}$ pools and flux in forest ecosystems. The 2 models reflect slightly different assumptions about changes in $\mathrm{C}$ in the various ecosystem components, most notably in soils. FORCARB assumes that $C$ levels undergo significant change in response to forest management activities. Carbon levels decrease after harvest and increase with extended forest growth (Birdsey 1991). Soil C levels are relatively insensitive to management activity in FCM, consistent with the work of Johnson (1992). Consequently, the FCM results show a slow but steady increase in $C$ levels, while the FORCARB results show steep increases in $C$ inventories which are then slowed by the harvest of trees as they reach financial maturity.

\section{SCENARIOS}

The baseline assumptions used in this analysis for the most part follow those used in the 1989 RPA Timber Assessment (Haynes 1990. Haynes \& Adams 1992). The baseline projects a growth in GNP of 2 to $3 \%$ over the $50 \mathrm{yr}$ projection period, increasing energy costs, and population increases of 333 million by 2040 consistent with 1990 census projections. Demand for 
forest products rises following population projections, but with a slowing of per capita demand. However, the National Forest timber harvest projections are reduced by approximately 0.5 billion cubic feet (ca $1.4 \times 10^{7} \mathrm{~m}^{3}$ ) per year to reflect revised National Forest management plans, additional restrictions on log exports, and harvest set-asides due to legal actions surrounding the Endangered Species Act. The baseline reflects activities on the National Forests as of 1992.

The analysis assumes that all trees planted and/or retained from harvest by the activities proposed here are available once they reach minimum harvest age. Minimum harvest age is approximately $20 \mathrm{yr}$ in the South, $45 \mathrm{yr}$ in the Pacific Coast states, and $70 \mathrm{yr}$ elsewhere. It is possible that forests planted under such programs might be managed for non-commodity values. We focused in this paper on analyzing the most extreme market case; managing the newly planted or retained forests for non-commodity values would likely mitigate the adverse economic effects reported here. The scenarios also assume that tree planting displaces no other activities and imposes no opportunity costs. We recognize that removing land from agricultural use imposes an opportunity cost (Winjum \& Lewis 1993). However, such an evaluation is impossible here since the agricultural land market is not included in the TAMM model.

\section{Tree planting programs}

Planting new forests on a large scale, or afforestation, reduces the rate of GHG emissions by increasing the storage of $\mathrm{CO}_{2}$ from the atmosphere (Dixon et al. $1993 a, b$ ). Uptake of $\mathrm{CO}_{2}$ in these new forests is especially rapid due to the high growth rates of young trees, especially coniferous trees grown in plantations. The U.S.'s America the Beautiful (ATB) Program was designed to plant 1 billion trees a year for 10 yr on privately owned lands. The program proposed expenditures of US\$110 million per year for rural tree planting, in addition to other expenditures on community tree programs.

Scenarios for rural tree planting using direct government expenditures of US\$ 110 and US\$220 million per year for 10 yr were designed. The $\$ 220$ million level is designed to represent a very aggressive level of accomplishment. While the ATB program was designed to use a 50/50 sharing of cost with landowners on forest establishment, we employed the method used in the Conservation Reserve Program, where the government rents the land for the first $10 \mathrm{yr}$ of the program, and pays either all or part of the establishment costs. This approach was also suggested by Moulton \& Richards (1990) in their work generating least-cost curves for renting lands suitable for planting trees to sequester $C$. Retention of land in trees after payments end is assumed to be between 85 and $95 \%$, based on previous experience with programs of this type (Kurtz et al. 1980). Land area is lost from the program at the rate of $0.3 \% \mathrm{yr}^{-1}$ for the first $10 \mathrm{yr}$ after payments end, and $0.1 \% \mathrm{yr}^{-1}$ every year thereafter.

The selection of lands at each expenditure level was simulated in each region using the least-cost schedules generated by both Moulton \& Richards (M\&R) and Parks \& Hardie (P\&H) (1992 unpubl. data). ${ }^{1}$ The 2 schedules use different rental and discount rates, amortization periods, and cost per $\mathrm{Mg}$ of $\mathrm{C}$ sequestered. They also differ in how much of the establishment costs are shared with the landowner 10 and $50 \%$ respectively).

Use of the 2 data sets gave the following schedules for enrolling privately owned lands in the program. At $\$ 110$ million, use of the $M \& R$ data resulted in 2.3 million hectares (ha) of plantings, with all land enrolled in the South-Central region. At the same level, the P\&H data resulted in 2.8 million ha of plantings, with SouthCentral planting greater than under M\&R, and with additional enrollments in the Northeast and Pacific Northwest. At the $\$ 220$ million level, $M \& R$ directed $81 \%$ of the 4 million ha enrolled to the South-Central region, with the remainder going to the Rocky Mountains. At the same funding level P\&H enrolled 5 million ha, with nearly equal area planted in the South-Central states as in M\&R, $20 \%$ of the total enrolled hectares in the North-Central region, and the remaining $10 \%$ spread among all other regions except the Rocky Mountains.

\section{Increased use of recycled fiber}

Increasing the use of recycled fiber in the manufacture of paper and board replaces a percentage of the newly harvested fiber in the production process. Using less virgin fiber reduces the harvest of trees and leaves more of the forest, and its $C$, intact to grow longer and to sequester more $\mathrm{C}$. The High Recycling scenario differs from the baseline in how quickly higher levels of recycled fiber use are attained, and in the magnitude of the final level. In the baseline, the percent of recycled fiber in the paper production process is $21 \%$ in 2000 and rises to $28 \%$ by 2040 . The High Recycling scenario achieves $45 \%$ utilization in the process by

\footnotetext{
${ }^{1}$ Data provided by P. J. Parks, Rutgers University, Cook College Department of Agricultural Economics, New Brunswick, NJ, and I. W. Hardie, University of Maryland Department of Agricultural and Resource Economics, College Park, MD
} 
2000 and maintains that level through 2040. The High Recycling scenario was derived from suggestions by the American Paper Institute.

\section{RESULTS}

Results are reported in terms of their impacts on 3 selected groups: consumers of forest products, producers (mostly industrial firms) of forest products, and timberland owners. In general, federal forest policies in the past have been considered effective if they did not reduce private timberland owners' wealth or greatly enrich the producers of forest products (Adams et al. 1977). The various measures were computed as part of the TAMM solutions and were measured following generally acceptable conventions, such as illustrated in Just et al. (1982). The welfare data from the product markets show the overall economic condition of product producers and consumers. Total welfare can be computed as the sum of consumer and producer surplus, ${ }^{1}$ which are presented here. We also include welfare estimates for forest landowners (stumpage producers), although estimates for the other

${ }^{1}$ The concept of economic surplus refers to the fact that we buy goods at the same price as we are willing to pay for the last unit exchanged of that good. Economic surplus, i.e. for consumers, is measured by the accumulated difference between the price we were willing to pay and the price of the last unit exchanged factor markets (labor and capital) are not available. Stumpage and product prices are given to illustrate the direct effect of these options on the market.

U.S. timberlands currently store between 31.6 and $36.2 \mathrm{Pg} \mathrm{C}$, based on the work reported here. We project this to increase to between 35.8 and $38.0 \mathrm{Pg}$ by the year 2040 under baseline conditions (an increase of between 1.8 and $4.2 \mathrm{Pg}$ ). Additional C conservation and sequestration due to implementation of scenarios are presented in Fig. 1. Increases in C range from 300 to $960 \mathrm{Tg}$ (teragrams, $\times 10^{12} \mathrm{~g}$ ) over the $50 \mathrm{yr}$ period. These translate to annual sequestration rates as high as $20 \mathrm{Tg} \mathrm{yr}^{-1}$ in the second decade for the High Recycling run, and $30 \mathrm{Tg} \mathrm{yr}^{-1}$ in the third decade for the most aggressive tree planting scenario.

\section{Tree planting programs}

The results from the Moulton \& Richards $\$ 110$ million (M\&R 110) and Parks \& Hardie $\$ 220$ million (P\&H 220) scenarios, which bound the tree planting results, illustrate the physical and economic outcomes. Increases in $\mathrm{C}$ conservation and storage are consistent with the land area planted (Fig. 1a), and result in equivalent regional distribution, as given above. Lumber and plywood prices fall with the increase in supply (Table 1), increasing consumer surplus (Table 2). Softwood harvests rise in the long run, consistent with the additional planted area in each region, for each scenario. Increases in production keep aggregate produc-

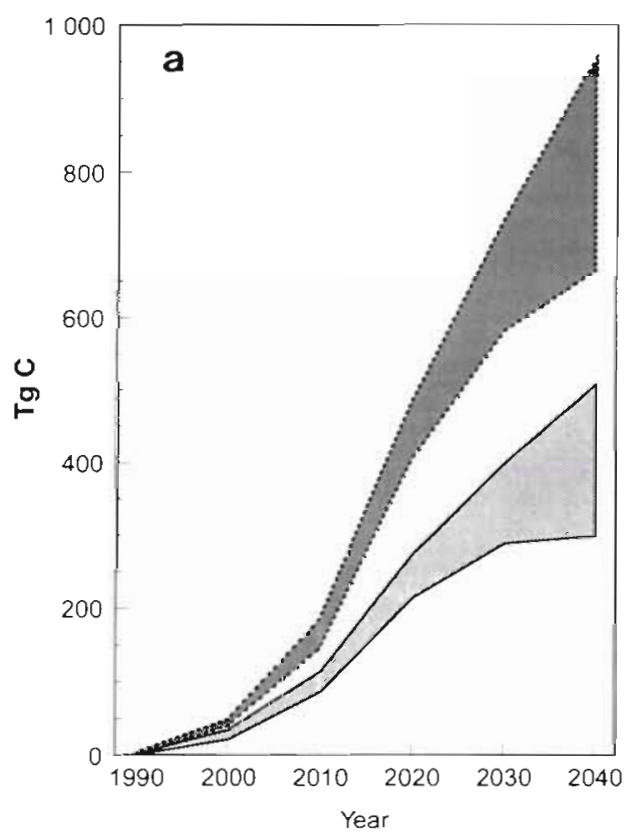

Moulton \& Richards 110 Parks \& Hardie 220

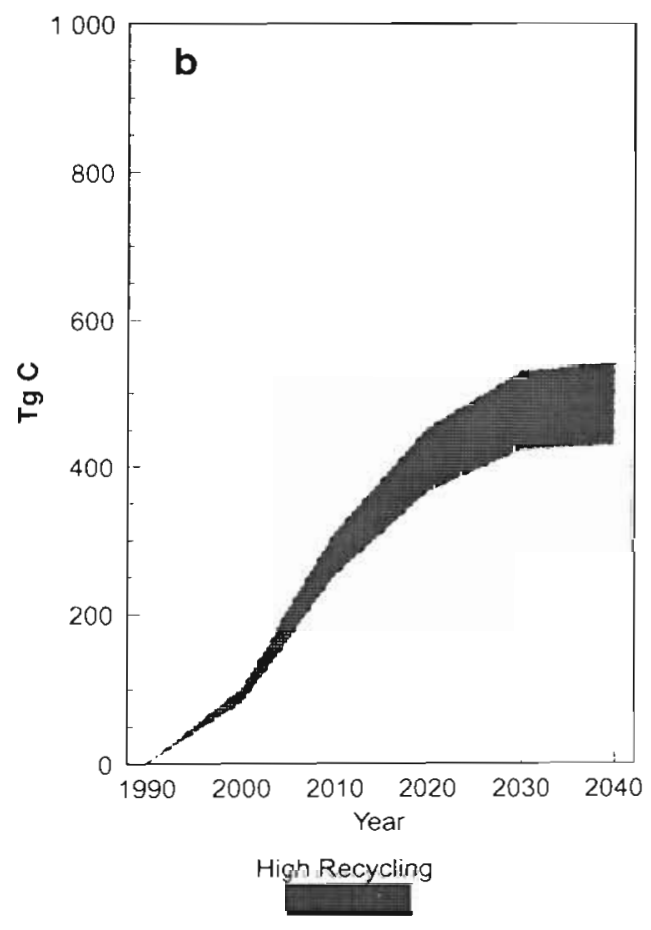

Fig. 1 Ranges for in creases in C in U.S. timberlands, cumulatively, above baseline for (a) 2 tree planting scenarios, and (b) high recycling scenario 
Table 1. Lumber price index, and stumpage prices in the South and Pacific Northwest for baseline and forest sector mitigation scenarios. Mbf $=1000$ board feet

\begin{tabular}{|lccccc|}
\hline Indicator & Year & Base & High Recycling & M\&R 110 & P\&H 220 \\
\cline { 6 - 6 } & - & & & & \\
Softwood lumber & 1990 & 390.0 & 389.3 & 390.0 & 390.0 \\
price index & 2010 & 605.0 & 569.5 & 612.3 & 612.7 \\
$(1990=100)$ & 2040 & 629.4 & 574.7 & 584.8 & 603.6 \\
South softwood & 1990 & 140.8 & 140.5 & 140.8 & 140.8 \\
stumpage prices & 2010 & 259.5 & 5.8 & 236.9 & 227.5 \\
(\$1990 US/Mbf) & 2040 & 296.8 & 164.9 & 0 & 0 \\
Pacific NW softwood & 1990 & 145.0 & 144.6 & 145.0 & 145.0 \\
stumpage prices & 2010 & 311.1 & 273.5 & 310.1 & 308.8 \\
(\$ 1990 US/Mbf) & 2040 & 358.2 & 236.4 & 279.6 & 246.5 \\
\hline
\end{tabular}

Table 2. Consumer, producer, and stumpage producer surplus effects of baseline and forest sector mitigation scenarios

\begin{tabular}{|c|c|c|c|c|c|}
\hline Indicator & Year & Base & High Recycling & $M \& R 110$ & P\&H 220 \\
\hline Consumer surplus, & 1990 & 108267 & 108325 & 108323 & 108323 \\
\hline$\$ 1990$ US & 2010 & 139506 & 141884 & 139499 & 139496 \\
\hline (million) & 2040 & 173166 & 179671 & 179711 & 181749 \\
\hline Producer surplus, & 1990 & 9454 & 9444 & 9453 & 9453 \\
\hline \$1990 US & 2010 & 15606 & 15689 & 16059 & 15962 \\
\hline (million) & 2040 & 21659 & 22144 & 21719 & 21710 \\
\hline Stumpage producer & 1990 & 2347 & 2338 & 2346 & 2346 \\
\hline surplus, \$1990 US & 2010 & 3990 & 1672 & 4007 & 3957 \\
\hline (million) & 2040 & 5882 & 4632 & 0 & 0 \\
\hline
\end{tabular}

ers' revenues (Fig. 2), and corresponding welfare, nearly level. Employment stays level or rises slightly (1 to $2 \%$ ) due to increases in tree planting, harvesting and production. Regional employment varies directly with regional harvest levels. The reductions in prices make U.S. products more competitive and imports of softwood lumber from Canada fall $42 \%$ by 2040. However, domestic forest landowners suffer considerable losses. The stumpage producer surplus for the entire U.S. forest sector is more than halved by 2040 under the $\$ 110$ million scenario, and is a residual value, or very low level, at the higher planting level (Table 2).

As trees are planted and grow to commercially viable size, the supply of wood increases, driving down the price of stumpage (Table 1). Stumpage price is the value of wood before harvest and transport, and represents the value of the resource to the timberland owner. This effect is felt most strongly in the South where most of the increase in planting takes place. Stumpage prices also fall in the Pacific Northwest, the Rockies, and the North

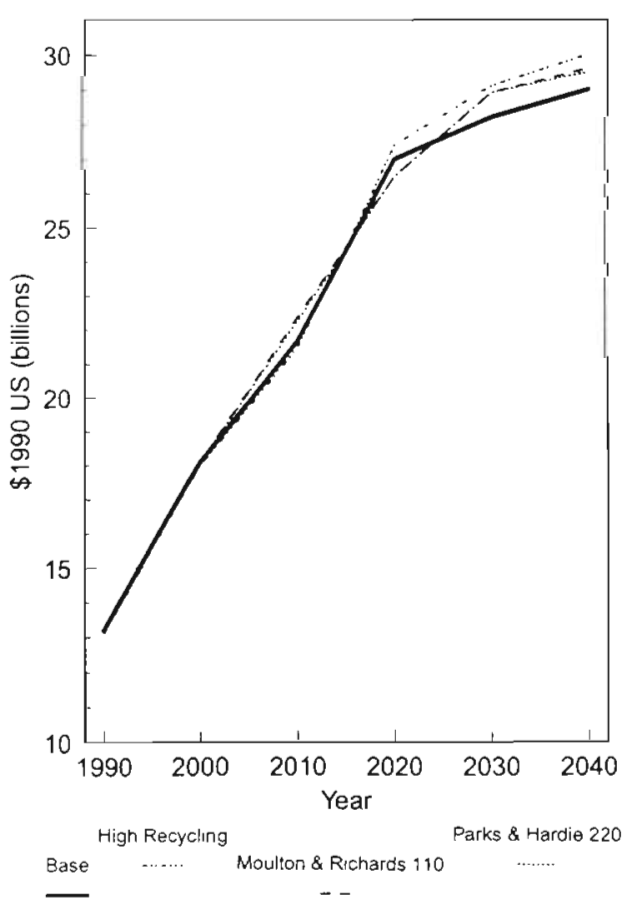

Fig. 2. Total revenues to U.S. lumber producers for baseline, high recycling, and 2 tree planting scenarios in one scenario, although not as dramatically. The result is that revenues to stumpage producers fall. In the most serious cases, stumpage values will fall to some small residual value (Fig. $3 a$ ).

One difficulty in modelling these tree planting runs is that TAMM does not include price-sensitive land management decisions. Such changes are treated exogenously. The current land management assumptions are consistent with recent trends, but tree planting at the scale envisioned in these scenarios has not been done and, consequently, no data exist on suitable investment responses. Historically, landowners have not responded to small-scale afforestation projects by divesting themselves significantly of their land and/or timber resources. The model projects that same response to the large-scale planting. Since there are no historic data on tree planting at this scale, the model may not project the most likely response to it.

This observed lack of significant divestment by landowners reflects an important aspect of forest land markets. Timberland owners have been shown to have an array of goals for their land, many of which do not involve producing commercial products. As such, their behavior cannot accurately be portrayed strictly as 


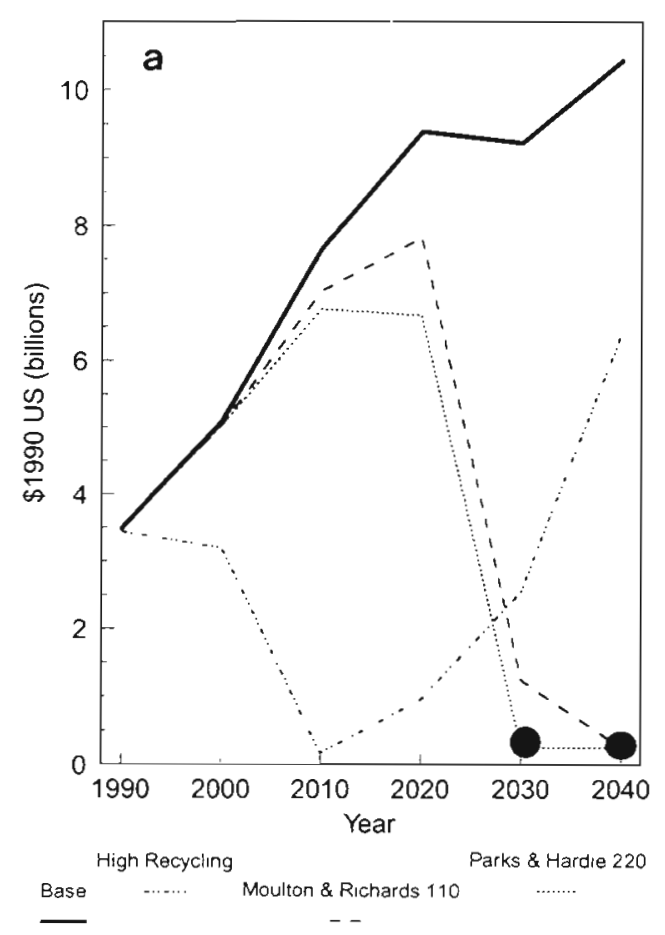

maximizing profit. Forest land markets show considerable 'stickiness' or investment decisions which do not generate optimum financial returns. Decisions of this type by themselves reduce the supply of available timber and offset some of the possible economic impacts of large-scale planting.

In reality, it is unlikely that forest landowners interested in growing commercial-quality timber for profit would sit idly while the value of their resource greatly diminishes. Landowners can respond to changes in the market by changing the management of the resources they hold (Newman \& Wear 1993). A lag of 20 to $30 \mathrm{yr}$ exists between the establishment of additional plantations and the time when these resources become financially mature. Since increases in supply make resources less valuable, wood producers would likely avoid losses by making adjustments in their forest land investments in expectation of the reductions in price. They may respond by cutting their lands early, by selling the land completely, by taking the land out of active management and keeping the wood off the market until the price rises, or by finding alternative markets for the resource.

\section{Increased use of recycled fiber}

Increasing the use of recycled fiber also increases the supply of standing timber, although it has a more immediate effect than planting new forests. Trees saved from harvest maintain and add to timber inventories in the near term, while newly planted trees require 2 or 3 decades to attain commercially profitable size before they affect prices. Consequently, the recycling scenario has some effects similar, though not equal, to those of the tree planting scenarios. As in the tree planting scenarios, the economic condition of forest product consumers is improved by increases in supply (Table 2). Unlike the tree planting scenario, however, the recycling scenario reduces harvesting for pulpwood, reducing forest sector employment by 1 to $7 \%$. The more drastic impacts are felt in the near term, before sawtimber harvests increase in the later decades. This analysis does not include employment related to the collection and processing of waste paper before it enters the paper mill, which if accounted for would likely offset some of the employment losses suffered in wood processing.

The more immediate effect of the High Recycling scenario is rapid increases in the $\mathrm{C}$ inventory relative to the baseline scenario as demand for fiber goes down (Fig. 1b). Slumping demand causes timber inventories to rise, driving down prices (Table 1) and stumpage revenues as in the tree planting scenarios (Fig. 3). Again, that result is felt more strongly in the South, which produces the bulk of paper pulp consumed in markets which would use recycled fiber. In the long run, pulpwood-sized trees grow enough to be cut for sawtimber. The availability of sawtimber leads to expanded lumber and plywood production, and prices rebound in later decades. 


\section{DISCUSSION}

Planting trees and increasing the use of recycled fiber are attractive options for $\mathrm{C}$ conservation and sequestration. From a physical perspective, these options maintain or increase the storage of $\mathrm{C}$ in terrestrial systems by increasing the inventory of trees. Economically, the options appear to be inexpensive relative to other regulatory or tax policies on the basis of dollars spent per $\mathrm{Mg}$ of $\mathrm{C}$ sequestered (Bradley et al. 1991). Recycling rates are increasing due to the preference of consumers and local and state governments based on concerns about conservation, landfill space and environmental quality (Alig 1992). Planting trees improves the physical environment and offers aesthetic benefits. There are, however, economic drawbacks to these activities.

As the data show, increasing the supply of commercially available wood lowers the price paid for stumpage, causing large losses to stumpage producers. In addition to the financial losses experienced by landowners, there are possible adverse outcomes from a $\mathrm{C}$ storage viewpoint. Landowners who wish to avoid losses may sell or cut their land in advance of expected price drops. Carbon emissions would increase immediately through the harvest activities, and possibly in the long term if the land were developed for a non-forest use.

The results indicate that while consumers and product producers may be affected very little by the type of mitigation strategies suggested here, these options are not without social costs. The challenge for policy makers is to understand the full range of potential physical and economic impacts, and to design policies which moderate the type of negative effects described here. Several examples illustrate the point.

- A planting program with a more even regional distribution would reduce the impacts on any one area, but would be more expensive and/or store less $C$ than one based on a least-cost distribution.

- A planting program designed to keep trees grown from entering the market after 30 to $50 \mathrm{yr}$ would completely counteract the negative effect on prices. It might, however, be difficult to keep land in the program without the financial incentive of future revenues.

- The government could purchase the land or continue to pay rent past the original $10 \mathrm{yr}$ term to ensure that the forests stayed intact. This would increase government costs or necessitate reducing the size of the program to keep expenditures level. It would also raise the effective cost per ton of $C$ sequestered (U.S. DOE 1991). Set-aside forest lands could be used to support recreation or other activities.
Using wood for bioenergy would increase demand for the trees outside of the traditional market and offset some of the increases in supply. It would also offset the use of some fossil fuels and the attendant $\mathrm{C}$ emissions. Biomass fuel stocks currently are more expensive then those of fossil fuels (Graham et al. 1992), and it is likely that such a program would require large subsidies, increasing the costs to either governments or energy users.

- Restricting timber harvests from public lands would constrain supply and raise the price of stumpage, offsetting the adverse effects of largescale plantings. It would also likely shift harvests to private lands, and in the near term, increase imports from Canada.

The list above suggests that while any action produces negative effects, combining options that have opposite effects may offer a way to alleviate the adverse impacts associated with any one option. In this instance, combining options which increase timber supply with options which increase demand or decrease supply may moderate the type of impacts reported here. More work is needed to quantify the effects of linking these activities.

\section{CONCLUSION}

The 3 options exhibited significant $C$ storage benefits in the U.S. However, they also increase the supply of commercially available timber, drive down stumpage prices, and have major economic impacts on timber growers (though very little effect on the welfare of product producers and consumers). Given the differences in the regional distribution of tree planting and paper markets, forest owners in the southern U.S. were more adversely affected than in other regions. This suggests that policies could be adjusted to spread effects more equitably across affected regions. It is also possible that market responses not accounted for in this modeling framework will come into force. The results also suggest that these adverse impacts may be moderated by linking options which have offsetting economic effects

The results presented here indicate that U.S. options which mitigate the buildup of GHG in the atmosphere may have negative impacts associated with them. Consequently, it is necessary to understand the nature, range, and possible magnitude of economic responses to any change in the market. Whether imposed by a federal program, or by consumer preference, adjustments are likely to be required in the design of GHG mitigation programs to meet the needs of consumers and producers in the forest sector. 
Acknowledgements. Although the research described in this article was supported by the U.S. Environmental Protection Agency through InterAgency Agreements with USDA Forest Service, it has not been subjected to Agency review and therefore does not necessarily reflect the views of the Agency or the USDA Forest Service and no official endorsement should be inferred. The authors thank R. Wolcott, I. Mintzer, K. Andrasko, J. Leggett, D. Tirpak, and R. Shackleton for their help in preparing this paper.

\section{LITERATURE CITED}

Adams, D. M., Haynes, R. W. (1980). The 1980 Softwood Timber Assessment Market Model: structure, projections, and policy simulations. For. Sci. Monogr. 22

Adams, D. M., Haynes, R. W. (1990). Future development of the Douglas-fir region forest economy under changing public policies and private responses. W. J. appl. For. 5(3): $64-69$

Adams, D. M., Haynes, R. W. (1991a). Softwood timber supply and the future of the Southern timber economy. S. J. appl. For. 15: $31-37$

Adams, D. M., Haynes, R. W. (1991b). Estimating the economic impacts of preserving old-growth on public lands in the Pacific Northwest. NW. environ. J. 6(2): 439-441

Adams, D. M., Haynes, R. W., Darr, D. R. (1977). A welfare analysis of long-term forest products price stabilization. Am. J. agricult. Econ. 59(4): 662-673

Alig, J. T (1992). Legislative trends in paper recycling. Recycled Paper News. Center for Earth Resource Management Applications, Springfield, VA, 3(3): 1-9

Birdsey, R. A. (1991). Impacts of U. S. forest management policies on the carbon cycle. In: Agriculture in a world of change. Proc. of Outlook 91, 67th Ann. Outlook Conf. USDA, Washington, DC, p. 348-359

Bradley, R. A., Watts, E. C., Williams, E. R. (eds.) (1991) Report to the Congress of the United States: Limiting net greenhouse gas emissions in the United States. Vol. 2. DOE/PE-0101 U.S. Department of Energy, Washington, $\mathrm{DC}$

Dixon, R. K., Winjum, J. K., Andrasko, K. J., Lee, J. J., Schoeder, P. E. (1993a). Integrated systems: assessment of promising agroforest and alternative land-use practices to enhance carbon conservation and sequestration. Clim. Change (in press)

Dixon, R. K., Winjum, J. K., Schroeder, P. E. (1993b). Conservation and sequestration of carbon: the potential of forest and agroforest management practices. Global Environ. Change (in press)

Graham, R. L., Wright, L. L., Turhollow, A. F. (1992). The potential for short-rotation woody crops to reduce U.S. $\mathrm{CO}_{2}$ emissions. Clim. Change 22: 223-238

Haynes, R. W (1990). An analysis of the timber situation in the United States: 1989-2040. USDA Forest Service Rocky Mountain Forest and Range Experiment Station Gen. Tech. Rep. RM-199. Ft Collins, CO

Haynes, R. W., Adams, D. M. (1985). Simulations of the effects of alternative assumptions on demand-supply determinants on the timber situation in the United States. U.S. Forest
Service, Forest Resources Economics Research, Washington, DC

Haynes, R. W., Adams, D. M. (1992). The timber situation in the United States: analysis and projections to 2040 J. For. 90(5): 38-43

Haynes, R. W., Kaiser, H. F. (1990). Forests: methods for valuing acidic deposition and air pollution effects. In: Irving, P. M. (ed.) Acidic deposition: state of science and technology, Vol. IV. Control technologies, future emissions, and effects valuation. Government Printing Office, Washington, DC, p. 27-109-27-115

Johnson, D. W. (1992). Effects of forest management on soil carbon storage. Wat. Air Soil Pollut. 64: 83-120

Just, R. E., Hueth, D. L., Schmitz, A. (1982). Applied welfare economics and public policy. Prentice-Hall, Englewood Cliffs, NJ

Kurtz, W. B., Mills, T J., Alig, R. J. (1980). Retention and conditions of Agricultural Conservation Program conifer plantings. J. For. $78(5): 273-276$

Mills, J. R., Kincaid, J. C. (1992). The Aggregate Timberland Assessment System - ATLAS: a comprehensive timber projection model. Gen. Tech Rep. PNW-GTR-281 USDA Forest Service PNW Research Station, Portland, OR

Moulton, R. J., Richards, K. R. (1990). Costs of sequestering carbon through tree planting and forest management in the United States. USDA Forest Service Gen. Tech. Rep. WO-58, Washington, DC

Newman, D. H. Wear, D. N. (1993). The production economics of private forestry: a comparison of industrial and nonindustrial forest owners. Am. J. Agricult. Econ. (in press)

Peer, R. L, CampbelI, D. L., Hohenstein, W. G. (1991). Global warming mitigation potential of three tree plantation scenarios. U.S. Environmental Protection Agency Office of Research and Development, EPA-600/7-91-003, Washington, $\mathrm{DC}$

Plantinga, A. J., Birdsey, R. A. (1993). Carbon fluxes resulting from U.S. private timberland management. Clim. Change 23: $37-53$

Turner, D. P., Lee, J. J., Koerper, G. J., Barker, J. R. (1993). The forest sector carbon budget of the United States: Carbon pools and flux under alternative policy options. EPA/600/3-93/093. U.S. Environmental Protection Agency, Office of Research and Development, Corvallis, OR

U.S. DOE (U.S. Department of Energy) (1991). Costs of meeting the emissions reduction targets established by the $\mathrm{CO}_{2}$ Offset Policy Efficiency Act of 1991: H. R. 2663. U.S Department of Energy, Washington, DC

U.S. DOE (U.S. Department of State) (1992). National action plan for global climate change. U.S. DOS Publication 10026. U.S. Department of State, Bureau of Oceans and International Environmental and Scientific Affairs, Office of Global Change, Washington, DC

Winjum, J. K., Lewis, D. K. (1993). Forest management and the economics of carbon storage: the nonfinancial component. Clim. Res. 3: 111-119

Wisniewski, J., Dixon, R. K., Kinsman, J. D., Sampson, R. N., Lugo, A. E. (1993). Carbon dioxide sequestration in terrestrial ecosystems. Clim. Res. 3: 1-5 